\title{
The effect of stylistic repetition in English-language advertising texts
}

\author{
H. Stashko \\ Kyiv National Linguistic University, Kyiv, Ukraine \\ Corresponding author. E-mail: halynastashkoknlu@gmail.com
}

Paper received 14.11.20; Accepted for publication 27.11.20.

https://doi.org/10.31174/SEND-Ph2020-241VIII72-13

\begin{abstract}
The article focuses on stylistic repetition, its effect and types in English-language advertising texts. Special attention is paid to anaphora and epiphora reinforced by alliteration and assonance, which appear the most popular and widely used stylistic devices contributing to emotional feedback and motivating consumers to buy the product while anadiplosis and epanalepsis are viewed quite scare and difficult to remember.
\end{abstract}

Keywords: stylistic repetition, anaphora, epiphora, anadiplosis, epanalepsis, alliteration, assonance, advertising text, brand slogans, manipulation technique.

Introduction. Today, advertising surrounds people everywhere, imposing ideas, motivating actions, informing about events or products. Every day, advertisers spend a lot of money on promoting their services and products to contribute to effectiveness. The manipulative nature of advertising makes a person buy the advertised goods, thereby bringing the advertiser considerable income. Obviously, advertising is beneficial to consumers too as they may be attracted by some goods they have never seen or heard of but might need.

Generally speaking, advertising is considered the most effective way to communicate to the customers and it has a central role to play in developing brand image [13]. According to Cambridge Dictionary [6], advertising is the business of trying to persuade people to buy products or services. This definition highlights the manipulative nature of adverting, which is linguistically presented by a bunch of various stylistic means, play the greatest role in the analysis of any kind of literary text. As ideas and appeals can be expressed in a variety of ways, any way used to advertise goods with the help stylistic means will be effective in swaying the target audience.

Review of publications. Previous studies explore the impact of sounds on different forms of persuasiveness $[2 ; 4$; 9] and some indicate that certain behavioural patterns in consumerism may depend on sticky slogans to convince people to try or buy a product [10]. Bernardi et al. [5] highlight the positive role of music in persuasion, while Erofeeva and Ushnikova [8] focus on elements of energy potential in advertising texts and Mcquarrie and Mick [12] explore figures of rhetoric and their effect on an audience, Katrandjiev et al. investigate the usage of rhetorical figures in Bulgarian [11] whereas Chetia [7] studies advertisement texts in India, etc.

However, the available scientific papers leave many unresolved issues. Despite the frequent appearance of research on repetition in advertising texts, they have been minimally incorporated into advertising research. Thus, the principal purpose of this work is to contribute a more systematic understanding of stylistic repetition in advertising language and its effect on the consumer.

Methods and material. To achieve the aim of the research, 100 volunteer respondents were involved in the survey, where they were offered the list of advertising slogans (first without graphical or sound supplement and then with) with every second containing repetition selected with the help of qualitative analysis applied. The respondents were asked to answer the survey questions specifying their emotions before and after the reading the ad, readiness to buy the advertised goods or services, possible reasons for their decisions. The final stage included linguistic interpretation of the obtained results and quantitative data processing.

Results and discussion. To understand the effect of repetition in advertising texts it is necessary to concentrate on its definition and types. The Free Dictionary [20] states that repetition is the repeated use of the same word or word pattern as a rhetorical device that creates a literary effect. It is a syntactic stylistic device meant to create vivid images and focus on their features, make the line memorable. Repetition applied to words creates the figures known as anaphora (beginning words), epiphora or epistrophe (ending words), epanalepsis (beginning and ending) and anadiplosis (ending and beginning) [12]. The results show that the types widely used in advertising texts include anaphora and epiphora whereas anadiplosis and epanalepsis are rather rare. Additionally, it is necessary to consider such phonetic devices as alliteration and assonance which accompany repetition and strengthen memorability.

Anaphora is a repetition of a word or expression at the beginning of successive phrases, clauses, sentences, or verses especially for rhetorical or poetic effect [14]. The results show that inn brand slogans anaphora is usually represented by either verbs (the Imperative Mood in particular) or adjectives. It is evident that it serves the purpose of delivering an artistic effect to a slogan making the lines rhythmic (see Pic.1), e.g., Have a break, have KitKat (KitKat chocolate bar); Open a Coke, open happiness (Coca Cola drink). This device is successfully used to appeal to the emotions of the buyers in order to encourage them to feel special if they buy the advertised goods. On the other hand, anaphorical adjectives persuade and inspire to follow the lifestyle. As adjectives are mainly used to describe emotional and physical state [16], their usage makes the audience feel motivated to follow the depicted lifestyle. Nice examples (Pic. 1) are Real ingredients, real taste (Knorr cheese risotto), Pro cameras. Pro display. Pro performance. (Apple IPhone 11 Pro) where pro stands for professional and More defined. More conditioned. More beautiful lashes. More than mascara with more black impact. (Estee Lauder mascara). The latter example shows how grammar can be neglected to win the effect made by anaphora. Another example of anaphora produced by Wrigley's Double your pleasure, double your fun with Wrigley's Doublemint gum (Wrigley's chewing gum) serves a good tool to ease memory work. Intensified by rhyme the slogan became 'sticky' and worked perfectly which was proven by increased sales and popularity. 

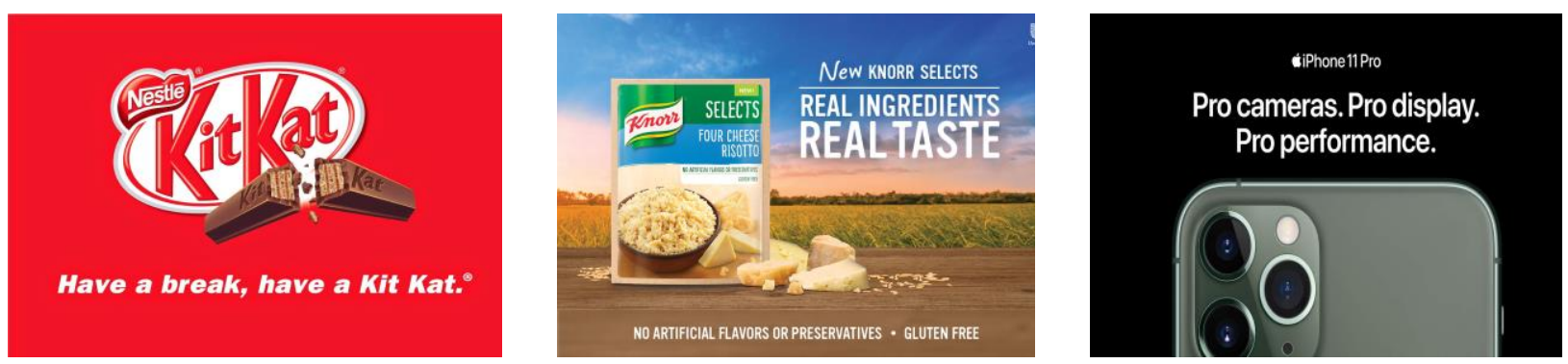

Picture 1. Anaphora in brand slogans. Source: free Internet files.

In this research anaphora proved to be most widely spread stylistic device professionally used in advertising texts. It also showed the highest result in the survey where 68 respondents out of 100 pointed its influence and memorable effect. Besides, a similar impact can be produced by alliteration, a phonetic stylistic means used to focus on the repetition of consonant sounds in close proximity in a phrase or utterance [14]. Both KitKat and Coca Cola intensified their brand names with this device. To illustrate alliteration, let's see how such brands as McDonald's and Arby's Bellmore (see Pic. 2) used it in their slogans to advertise food. Here 15 respondents out of 100 noticed the reference to the meat the sandwiches are made of. Initial ' $\mathrm{B}$ ' in beef is repeated in all the words in the slogans big. beefy. bliss and Bourbon BBQ attracting attention both visually and phonetically. Sound symbolism in alliteration is usually subtle and mainly works subconsciously [19]. According to some studies [17; 21]/b/ is perceived 'big'. Moreover, the repeated phoneme /i:/ [1; $3 ; 15 ; 21]$, which is known as assonance and focuses on the repetition of vowel sounds, is found 'continuous' and 'visible in terms of quantity'. Combined together they reinforce each other depicting sandwiches bigger with much meat and endless, continuous pleasure to taste them. Some respondents mentioned the size of sandwiches and pointed at their feelings and graphical images ('meat is shown big in amount in photos' [sic]).
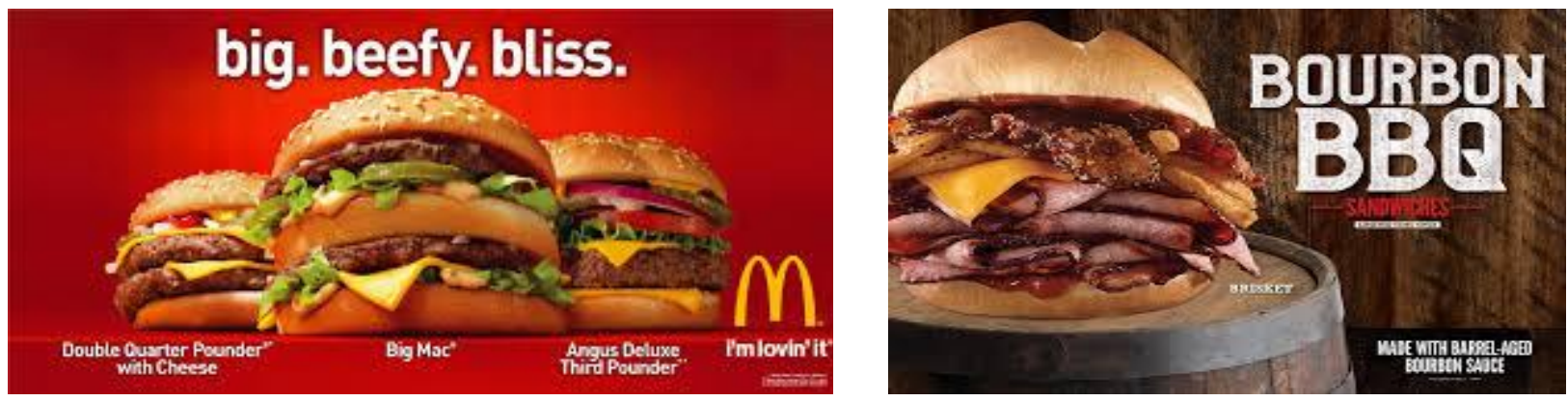

Picture 2. Alliteration in brand slogans (initial position). Source: free Internet files.

In contrast to anaphora, it is worth mentioning the impact of epiphora in advertising texts. Epiphora (epistrophe) is a repetition of a word or expression at the end of successive phrases, clauses, sentences or verses, especially for rhetorical or poetic effect [14]. It has been found out that this stylistic device is the third (after anaphora and polysyndeton) in usage and the second (after anaphora) effect. 46 respondents out of 100 mentioned its impact with two adverts winning (see Pic. 3 below). The brand Dr. Pepper used the word 'pepper' so many times (I'm a pepper. He's a pepper. She's a pepper. We're a pepper. Wouldn't you like to be a pepper too?) that it was next to impossible to forget it. Moreover, the image of a cute kitty also contributed to positive feedback - every respondent mentioned its level of cuteness. The slogans that collected the highest score also include Skittles candy drops. Rainbow is repeated twice to portray the skittles as rainbows because they are colorful, which is repeated third time graphically (noticed by 17 respondents). McDonald's also has an advert featuring epiphora. Wholesome. Have some. welcomes a wholesome burger meant for healthy lifestyle fans. A similar style was used by Samsung to advertise their phones SGH-D500. The right thing says everything. is only part of their advertising style and their customers may easily track Samsung goods for the word 'everything'. For example, their Voice Guide has the very word too: Samsung provides many accessibility options for our customers. One of them is the Voice Guide, which will announce everything you do on the TV. Turning it off will stop the TV from saying everything you do. 13 respondents paid their attention to it and 4 mentioned they were loyal customers of Samsung.

\section{TOUCH TIS RANBOW}

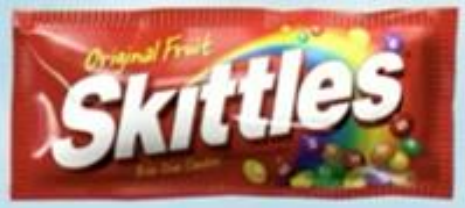

TASTE TUE RANNBOW

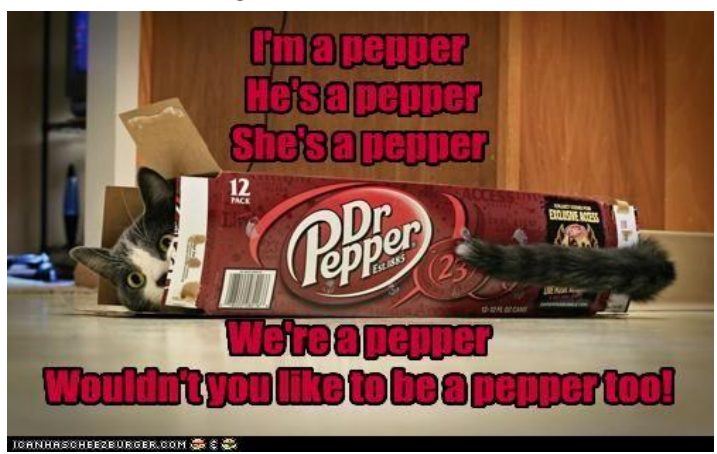

Picture 3. Epiphora in brand slogans. Source: free Internet files. 
Similarly, alliteration in the final position can serve effectively especially when the advert is accompanied by images and sounds. Heinz trademark (Pic. 4) implied this stylistic device laying emphasis on several particular points altogether: product, brand name, colour. What is more, these three words Beanz. Meanz. Heinz. perfectly rhyme and this factor most probably contributed to a funny result: only one respondent noticed incorrect grammar in 'beans' and 'means' and 88 additionally correlated orange colour with the colour of tinned beans. Tic Tac is an example of minimalistic wording but maximum effect emphasized by anaphora and epiphora.
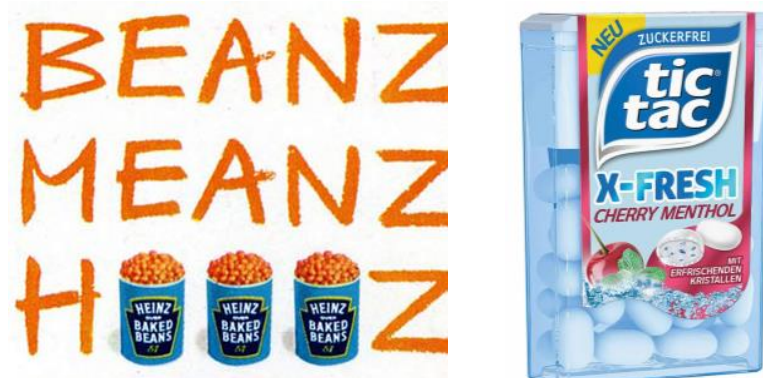

Picture 4. Alliteration in brand slogans (final position). Source: free Internet files.

It is no wonder that repeated beginnings and endings help concentrate attention. Similar impact was tracked in public speeches [18], where they may seem overwhelming and oversaturating the speech from the first point of view, but this is how they create certain rhythm; they help avoid monotonousness and therefore draw attention. Besides, they have an expressive function to specify information and focus on detail.

Both epiphora, or epistrophe, and anaphora reinforced by alliteration, assonance and rhyme serve the function of furnishing an artistic effect to slogans and brand names. These stylistic devices lay emphasis on a particular detail in a slogan, as well as giving it a unique rhythm, which consequently becomes a memorable experience for the consumer. That makes up the reason why such slogans are easily understood, memorized and followed.

Two more stylistic devices used in adverts are epanalepsis and anadiplosis. Epanalepsis is a figure by which the same word or clause is repeated after intervening matter [14] and anadiplosis is repetition of a prominent and usually the last word in one phrase or clause at the beginning of the next (as in "rely on his honor - honor such as his?") [ibid.]. Their primary functions are to add rhythm and cadence and build in intensity to a climax. Being quite popular among public speakers [18] they anyway appear rather rare in slogans. The most obvious reason lies in the structure and number of words. To be sticky and easy to remember slogans require minimum wording while anadiplosis and epanalepsis are flamboyant and extended. The only advert with epanalepsis which impressed the respondents referred to IPhone 6 (Pic. 5). The comment they left described the reason that is connected to high popularity of the brand heated by abundant manipulative techniques in promotion.

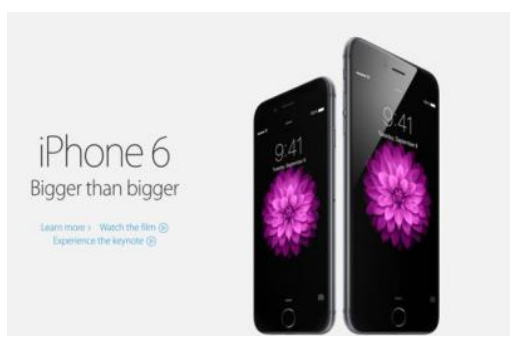

Picture 5. Epanalepsis in brand slogans. Source: free Internet files.

The only commented slogan with anadiplosis was produced by Direct TV. To ridicule old-fashioned cable TV, Direct TV created a series of ads showing that having cable inevitably leads to misery, self-destruction and personal degradation. Only 7 respondents found the ad catchy while 61 pointed at its 'philosophical view' [sic]. The very advertisement claims that:

When your cable company keeps you on hold, you get angry.

When you get angry, you go blow off steam.

When you go blow off steam, accidents happen.

When accidents happen, you get an eye patch.

When you get an eye patch, people think you're tough.

When people think you're tough, people want to see how tough.

And when people want to see how tough, you wake up in a roadside ditch.

Don't wake up in a roadside ditch.

Get rid of cable and upgrade to Direct TV.

Conclusions. From the outcome of the research it is possible to conclude that anaphora and epiphora are the handiest stylistic devices to promote goods and services. Catchy slogans must be short and rhythmic to be memorized and followed. Together with quality graphics and quality goods such adverts work productively and evoke positive feelings. In most cases the respondents were ready to buy the advertised product (86\%) and almost all of them were ready to taste or try the product (94\%). Thus, it has been demonstrated that as a rhetorical or stylistic device, repetition is brought into action to appeal to the emotions of the audience in order to persuade them to buy. Small words produce impressive impact and generate big ideas. It is clear that advertising is an integral part of our reality and therefore it should be examined to track its persuasive impact. In future, it might also be useful to investigate the effect of sound symbolism and persuasiveness in advertising texts.

\section{ЛИТЕРАТУРА}

1. Сташко Г.І. Жіночі образи в американському пісенному фольклорі: лінгвостилістичний та лінгвокультурологічний аспекти / Дис. ... канд. філол. наук / Київський національний лінгвістичний університет. 10.02.04 - германські мови. Київ, 2016.

2. Сташко, Г.І. Засоби стилістичної фонетики у створенні жіночих образів (на матеріалі американського пісенного фольклору) // Наукові записки національного університету

"Острозька академія". Серія: Філологічна, 2014. Вип. 44. С. 293-295.

3. Agrawal, P.K. Theory of phonosemantics, 2009. Available at: http://soundmeanings.com/pdf/English\%20-4.pdf

4. Benczes, R. The role of alliteration and rhyme in novel metaphorical and metonymical compounds // Metaphor and Symbol, 2013. 28(3). P. 167-184. 
5. Bernardi, L., Porta, C. \& Sleight, P. Cardiovascular, cerebrovascular, and respiratory changes induced by different types of music in musicians and non-musicians: the importance of silence // Heart, 2006. 92(4), P. 445-452.

6. Cambridge Dictionary. Available at: https://dictionary.cambridge.org/

7. Chetia, B. Rhetorical devices in English advertisement texts in India: A descriptive study // International Journal of Social Science and Humanity, 2015. Vol. 5, No. 11, P. 980-984.

8. Erofeeva, I. \& Ushnikova, O. Media text energy as collective cultural memory reflection // Lege artis. Language yesterday, today, tomorrow. The journal of University of SS Cyril and Methodius in Trnava, 2017. Warsaw: De Gruyter Open, II (2), P. 1-46. DOI: 10.1515/lart-2017-0012

9. Guerini, M., Ozbal, G. \& Strapparava, C. Echoes of persuasion: The effect of euphony in persuasive communication // Human language technologies: The 2015 Annual Conference of the North American Chapter of the ACL, pages 1483-1493, Denver, Colorado, May 31 - June 5, 2015.

10. Heath, Ch. \& Heath, D. Made to stick: Why some ideas survive and others die. 2007. Random House.

11. Katrandjiev, H., Velinov. I. \& Radova, K. Usage of rhetorical figures in advertising slogans // Trakia Journal of Sciences, 2016. No 3, P. 267-274.

12. Mcquarrie, E.F. \& Mick, D.G. Figures of rhetoric in advertising language // Journal of Consumer Research, 1996. 22, P. 424-438.

13. Meenaghan, T. The role of advertising in brand image development // Journal of Product \& Brand Management, 1995. Vol. 4,
No. 4. P. 23-34. DOI: 10.1108/10610429510097672

14. Merriam Webster Online Dictionary. Available at: https://www.merriam-webster.com/dictionary/

15. Panasenko, N. Musical and linguistic means of creating images in traditional and popular American songs // Review of Arts and Humanities, 2014. 3(1), P. 23-43.

16. Panasenko, N. The role of syntactic stylistic means in expressing the emotion term love // Research in Language. The Journal of University of Lodz, 2013. Vol. 11 (3). DOI: 10.2478/v10015012-0016-6.

17. Stashko, H. Sound symbolism in female images creation (based on American song folklore) // Science and education a new dimension. Philology, 2016. IV (20), Iss. 85, P. 60-63. Available at:

http://seanewdim.com/uploads/3/4/5/1/34511564/fil_iv20_85.pdf

18. Stashko, H. Phonetic and syntactic stylistic means in media space: Manipulation or emotional commonplace? // Communication Today, 2018. Vol. 9, No. 2, P. 132-142.

19. Stashko, H. When phonetics matters: Creation and perception of female images in song folklore // Lege artis. Language yesterday, today, tomorrow. The journal of University of SS Cyril and Methodius in Trnava, 2017. II (1), P. 299-335. DOI: 10.1515/lart-2017-0008

20. The Free Dictionary. Available at: https://www.thefreedictionary.com/

21. Thompson, P.D., Estes, Z. 2011. Sound symbolic naming of novel objects is a graded function // The Quarterly Journal of Experimental Psychology, 2011. 64 (12), P. 2392-2404.

\section{REFERENCES}

1. Stashko, H.I. Female images in American song folklore: Linguostylistic and linguoculturological aspects. Thesis for the Candidate Degree in Philology, Speciality 10.02.04 - Germanic Languages. Kyiv National Linguistic University, Kyiv, 2016.

2. Stashko, H.I. Засоби стилістичної фонетики у створенні жіночих образів (на матеріалі американського пісенного фольклору) Means of stylistic phonetics in creating female images (based on American song folklore) // Scientific Proceedings of the National University of "Ostroh Academy". "Philology" Series, 2014. Iss. 44. P. 293-295. 